\title{
PENINGKATAN HASIL BELAJAR IPA PESERTA DIDIK MENGGUNAKAN MODEL PEMBELAJARAN MAKE A MATCH PADA KELAS 4 SD
}

\author{
Wahyu Tri Raharjo \\ Pendidikan Guru Sekolah Dasar FKIP UKSW \\ raharjowahyutri@gmail.com \\ Firosalia Kristin \\ Pendidikan Guru Sekolah Dasar FKIP UKSW \\ firosalia.kristin@uksw.edu
}

\begin{abstract}
This study aims to determine the steps to implement the Make a Match learning model and improve learning result sains through the application of the Make a Match learning model to Grade IV students of Kutowinangun State Elementary School 04 Salatiga. This type of research is Classroom Action Research (PTK) with research subjects in 4th grade students of Kutowinangun State Elementary School 04 Salatiga consisting of 13 male students and 15 female students. The data collection technique used is test. The procedure of action research consists of two cycles. Each cycle through four stages of research includes: planning, action, observation, and reflection. The data analysis technique used was quantitative descriptive and qualitative descriptive. The percentage of completeness of learning result showed that in pre-action as many as 4 students completed (14\%), increased to 16 students completed (57\%) in the first cycle, and increased to 26 students completed (93\%) in second cycle. From this data it can be conclude through the application of the Make a Match learning model can improve the learning resulth sains of 4th grade students of Kutowinangun State Elementary School 04 Salatiga.
\end{abstract}

Keyword: make a match learning model, science learning, learning result, elementary school.

\section{PENDAHULUAN}

Pembelajaran IPA di sekolah bertujuan menguasai standar kompetensi yang telah ditetapkan, oleh karena itu pembelajaran IPA harus dibuat menarik dan mudah dipahami. Selain itu muatan pelajaran IPA cenderung kurang disukai peserta didik sehingga membuat nilai peserta didik pada muatan pelajaran ini kurang baik. Untuk mengatasi hal tersebut hal yang perlu dilakukan adalah menggunakan model yang tepat dalam pembelajaran tersebut. Menurut Sakarebau, (2017) Belajar adalah kegiatan yang aktif dimana subjek belajar membangun sendiri pengetahuannya. Subjek belajar juga mencari sendiri makna dari suatu yang mereka pelajari, seseorang akan berhasil dalam belajar, kalau dirinya sendiri ada keinginan untuk belajar.

Penerapan model pembelajaran diharapkan dapat membantu efektivitas dan efisien dalam proses pembelajaran serta penyampaian pesan dan isi pembelajaran pada saat itu. Mengingat muatan pelajaran IPA termasuk salah satu muatan pelajaran yang diujikan dalam ujian nasional, seharusnya nilai peserta didik pada muatan pelajaran IPA dapat mencapai nilai standar minimal yang telah ditentukan bahkan melebihi standar yang ditentukan.

Menurut Slameto (2003) menyatakan bahwa "hasil belajar adalah suatu proses usaha yang dilakukan seseorang untuk memperoleh suatu perubahan tingkah laku yang baru secara keseluruhan sebagai hasil pengalamannya sendiri dalam interaksi dengan 
lingkungannya". Sedangkan Menurut Sudjana (2008) Hasil belajar siswa pada hakikatnya adalah perubahan tingkah laku sebagai hasil belajar dalam pengertian yang lebih luas mencakup bidang kognitif, afektif, dan psikomotorik.

Berdasarkan hasil wawancara dengan wali kelas dan peserta didik kelas 4 SD Negeri Kutowinangun 04 Salatiga pada hari senin 6 september 2018, bahwa muatan pelajaran yang termasuk hasil belajarnya rendah adalah muatan pelajaran IPA, selain itu dari hasil observasi yang dilakukan menunjukan bahwa kerjasama antara peserta didik dengan peserta didik juga kurang terjalin dengan baik, karena peserta didik lebih cenderung bekerja sendiri daripada bekerjasama dengan lainnya. Muatan pelajaran IPA sangat penting untuk dipelajari, hal ini dikarenakan pembelajaran IPA di SD bertujuan agar peserta didik memiliki kemampuan diantaranya dapat diterapkan dalam kehidupan sehari-hari, mengembangkan rasa ingin tahu, sikap positif, dan kesadaran tentang adanya hubungan yang saling mempengaruhi antara IPA. Berdasarkan kenyataan yang ada, kebanyakan peserta didik beranggapan pembelajaran IPA merupakan muatan pelajaran yang membosankan, pelajaran yang sulit karena materi yang kompleks. Materi yang banyak membuat peserta didik merasa terbebani dalam pembelajaran.

Model pembelajaran adalah suatu perencanaan atau suatu pola yang digunakan sebagai pedoman dalam merencanakan pembelajaran di kelas atau pembelajaran dalam tutorial (Trianto, 2010). Menurut Sugiyanto, (2010) Make a Match merupakan teknik belajar mengajar mencari pasangan salah satu keunggulan teknik ini adalah siswa mencari pasangan sambil belajar mengenai suatu konsep atau topik dalam suasana yang menyenangkan. Sedangkan menurut Wiguna, dkk (2014) menyatakan bahwa model pembeljaran Make A Match (Mencari Pasangan) merupakan model pembelajaran yang aktif, kreatif, efektif, dan menyenangkan (PAKEM). Pembelajaran kooperatif yang mengutamakan kerjasama dan kecepatan di antara siswa untuk mencapai tujuan pembelajaran. Model pembelajaran ini memiliki ciri-ciri yaitu untuk menuntaskan materi belajarnya, siswa belajar dalam kelompok atau bersama siswa lain.

Penerapan model Make a Match diharapkan dapat memperbaiki pemahaman peserta didik dan hasil belajar IPA peserta didik sehingga dapat memenuhi kriteria ketuntasan minimal yang ditentukan oleh sekolah. Salah satu keunggulan model ini yaitu peserta didik mencari pasangan sambil belajar mengenai suatu konsep atau topik pembahasan dalam suasana yang menyenangkan. Selain itu peserta didik juga dapat belajar dalam suasana yang baru dan berbeda dari yang biasanya hanya serius. Dengan penerapan model pembelajaran Make a Match maka peserta didik dapat bermain namun juga tetap mendapatkan ilmu dari permainan yang diterapkan. Langkah- langkah Make a Match menurut Curran (Rusman, 2012: 223-224) adalah: (1) guru menyiapkan beberapa kartu yang berisi beberapa konsep/ topik yang cocok untuk sesi review (satu sisi kartu berupa kartu soal dan sisi sebaliknya berupa kartu jawaban). (2) setiap peserta didik mendapat satu kartu dan memikirkan jawaban atau soal dari kartu yang dipegang. (3) peserta didik mencari pasangan yang mempunyai kartu yang cocok dengan kartunya (kartu soal/ kartu jawaban). (4) peserta didik yang dapat mencocokan kartunya sebelum batas waktu diberi poin. (5) setelah satu babak kartu dikocok lagi agar tiap peserta didik mendapat kartu yang berbeda dari sebelumnya, demikian seterusnya. (6) membuat kesimpulan. 


\section{METODE PENELITIAN}

Jenis Penelitian ini adalah PTK atau Penelitian Tindakan Kelas. Menurut Iskandar (2012) PTK adalah bagian dari penelitian tindakan (action research) yang dilakukan oleh guru dan dosen di kelas (sekolah dan perguruan tinggi) tempat ia mengajar dengan tujuan memperbaiki dan meningkatkan kualitas proses belajar di kelas. Menurut Ariyanto (2016) Penelitian Tindakan Kelas adalah penelitian yang dilakukan oleh guru kelas dan memperoleh permasalahan yang diperoleh didalam kelas dan diselesaikan didalam kelas secara tersetruktur sesuai dengan langkahlangkah PTK dan hasil pemecahan masalah dapat dipergunakan untuk meningkatkan kecakapan kinerja guru di sekolah.

Teknik pengumpulan data menggunakan tes dan dokumentasi. Teknik tes digunakan untuk mengukur seberapa jauh penguasaan peserta didik terhadap materi, baik sebelum maupun sesudah pelaksanaan tindakan. Sedangkan teknik dokumentasi adalah mencari data mengenai variabel yang berupa catatan, transkip nilai dan profil sekolah. Teknik analisis data menggunakan analisis data kuantitatif, analisis data kualitatif, dan analisis data dokumentasi.

\section{HASIL PENELITIAN DAN PEMBAHASAN Hasil Penelitian}

Penelitian dilaksanakan dari bulan Januari 2019 sampai bulan mei 2019 di kelas 4 SD Negeri Kutowinangun 04 Salatiga. Pada tahap awal peneliti melakukan observasi yang bertujuan memperoleh data dan informasi mengenai permasalahan yang terjadi di lapangan serta menentukan fokus penelitian dalam menangani permasalahan pembelajaran di SD Negeri Kutowinangun 04 Salatiga. Pada tahap awal ini peneliti mengobservasi dalam kegiatan belajar mengajar pada muatan pembelajaran IPA, sedangkan pelaksanaan penelitian di laksanakan selama bulan April 2019. Siswa kelas 4 SD Negeri Kutowinangun 04 berjumlah 28 peserta didik. Subjek penelitian sebanyak 28 peserta didik tersebut yang terdiri dari 15 peserta didik perempuan dan 13 peserta didik laki-laki.

Berikut ini dapat dilihat peningkatan hasil belajar IPA peserta didik mulai dari kondisi awal (pra siklus), siklus I dan siklus II siswa kelas 4 SD Negeri Kutowinangun 04 Salatiga tahun ajaran 2018/2019 dengan menggunakan model pembelajaran Make a Match:

Tabel 1.

Peningkatan Hasil Belajar IPA Pra Siklus, Siklus I, dan Siklus II

\begin{tabular}{|c|c|c|c|c|c|c|c|}
\hline \multirow{2}{*}{$\begin{array}{r}\text { Peru- } \\
\text { bahan }\end{array}$} & \multirow{2}{*}{$\begin{array}{r}\text { Indi- } \\
\text { kator }\end{array}$} & \multicolumn{2}{|c|}{ Pra siklus } & \multicolumn{2}{|c|}{ Siklus I } & \multicolumn{2}{|c|}{ Siklus II } \\
\hline & & Frekuensi & Persentase & Frekuensi & Persentase & Frekuensi & Persentase \\
\hline \multirow{5}{*}{$\begin{array}{r}\text { Hasil } \\
\text { Belajar }\end{array}$} & Perse & 4 & $14 \%$ & 14 & $57 \%$ & 26 & $93 \%$ \\
\hline & ntase & & & & & & \\
\hline & Ketun & & & & & & \\
\hline & Krite- & \multirow{2}{*}{\multicolumn{2}{|c|}{ Kurang }} & \multirow{2}{*}{\multicolumn{2}{|c|}{ Baik }} & \multirow{2}{*}{\multicolumn{2}{|c|}{ Sangat Baik }} \\
\hline & $\begin{array}{r}\text { ra } \\
\text { Kelas }\end{array}$ & & & & & & \\
\hline
\end{tabular}


Berdasarkan data diatas dapat dilihat bahwa pada tahap pra siklus peneliti belum menerapkan penggunaan metode pembelajaran Make a Match dikarenakan untuk mengetahui seberapa besar persentase siswa yang memenuhi Kriteria Ketuntasan Minimal pada muatan pembelajaran IPA, pada tahap pra siklus hanya terdapat 4 orang peserta didik atau $14 \%$ peserta didik dari keseluruhan peserta didik kelas IV yang berpengetahuan awal mememuhi KKM. Sedangkan 24 peserta didik lainnya masih belum memenuhi KKM. Pada tahap siklus I peneliti sudah mulai menerapkan metode pembelajaran Make a Match dalam proses pembelajaran dan hasilnya menunjukan terjadinya peningkatan hasil belajar peserta didik dari tahap pra siklus ke siklus I, bahwa terdapat 16 peserta didik atau $57 \%$ peserta didik dari keseluruhan siswa kelas IV yang berpengetahuan awal memenuhi KKM, sedangkan 12 peserta didik lainnya masih belum memenuhi KKM. Pada tahap siklus II peneliti kembali menerapkan metode pembelajaran Make a Match dalam pembelajaran IPA di Kelas IV dan terjadi peningkatan hasil belajar peserta didik yang menunjukan bahwa terdapat 26 peserta didik atau $93 \%$ peserta didik dari keseluruhan peserta didik di kelas IV yang berpengetahuan awal memenuhi KKM, Sedangkan hanya 2 peserta didik yang masih belum memenuhi KKM.

Berikut mengenai peningkatan hasil belajar peserta didik SD Negeri Kutowinangun 04 Salatiga pada saat Pra siklus, siklus I, dan siklus II, maka dapat dilihat pada gambar diagram batang 1 :

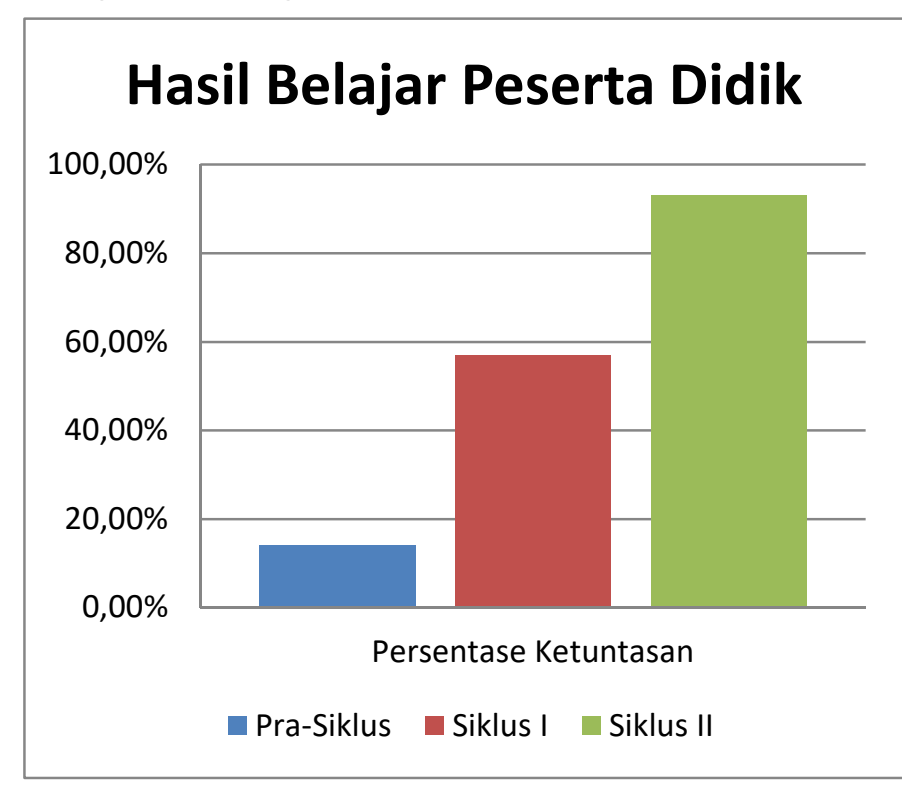

Gambar 1.

Persentase Hasil Belajar Peserta Didik

Berdasarkan Gambar 1 Persentase Hasil Belajar Peserta Didik diperoleh data bahwa persentase ketuntasan hasil belajar peserta didik pada kondisi awal yaitu $14 \%$ meningkat menjadi $57 \%$ pada siklus I atau meningkat sebanyak $43 \%$. Persentase ketuntasan pada siklus II yaitu 93\% yang artinya mengalami peningkatan dari siklus I sebanyak $36 \%$. 


\section{Pembahasan}

Hasil penelitian yang dilakukan oleh peneliti pada peserta didik kelas 4 SD Negeri Kutowinangun 04 Salatiga dengan menggunakan model pembelajaran Make a Match terlihat terjadi peningkatan pada hasil belajar IPA peserta didik pada pembelajaran tematik mulai dari kondisi awal (pra siklus), siklus I sampai siklus II. Peningkatan hasil belajar IPA peserta didik pada pembelajaran tematik juga mengalami peningkatan mulai dari kondisi awal (pra siklus) dengan persentase ketuntasan hasil belajar peserta didik pada kondisi awal yaitu 14\% meningkat menjadi 57\% pada siklus I atau meningkat sebanyak 43\%. Persentase ketuntasan pada siklus II yaitu 93\% yang artinya mengalami peningkatan dari siklus I sebanyak 36\%. Dari hasil belajar tersebut terlihat bahwa ranah pengetahuan peserta didik mengalami peningkatan, akan tetapi pada ranah sikap dan keterampilan peserta didik pun ikut mengalami peningkatan menjadi lebih baik lagi karena pengalaman-pengalaman belajar yang tidak hanya berfokus pada ranah kognitif saja.

Hasil penelitian diatas sejalan dengan teori hasil belajar yang dikemukakan oleh Samino dan Marsudi (2015) belajar merupakan suatu usaha yang dilakukan oleh peserta didik agar mendapatkan perubahan, yang meliputi aspek perubahan kognitif, afektif dan psikomotor. Sejelan dengan pendapat diatas penelitian ini menilai segi kognitif peserta didik. Hasil belajar dalam penelitian ini dapat dilihat dari pre-test hingga post-test. Lie (Yanti, dkk 2016) menjelaskan bahwa model kooperatif tipe Make A-Match dapat meningkatkan partisipasi siswa dalam pembelajaran, cocok digunakan untuk tugas sederhana, siswa lebih banyak kesempatan untuk kontribusi masing-masing anggota kelompok, dan interaksi di dalam pembelajaran lebih mudah serta cepat membentuknya sehingga siswa akan lebih mudah menemukan dan memahami materi yang disampaikan.

Pada saat mencari pasangan, suasana belajar yang tercipta adalah kompetisi antar siswa. Suasana kompetisi mendorong siswa untuk belajar lebih baik lagi, sebagaimana diungkapkan oleh Sofyan dan Uno (Artawa dan Suwatra, 2013), suasana persaingan akan memberikan kesempatan kepada peserta didik untuk mengukur kemampuan dirinya melalui kemampuan orang lain. Selain itu, belajar dengan bersaing akan menimbulkan upaya belajar yang sungguh sungguh. Melalui penelitian ini membuktikan bahwa model pembelajaran Make A-Match memberikan pengaruh positif terhadap hasil belajar peserta didik.

Berdasarkan uraian di atas maka, terdapat peningkatan hasil belajar siswa kelas 4 dari penelitian Pra siklus, Siklus I dan Siklus II. Pada penelitian prasiklus, proses pembelajaran belum menerapkan model pembelajaran Make a Match sehingga peserta didik terlihat kurang aktif dalam mengikuti proses pembelajaran. Pada siklus I, proses pembelajaran dilaksanakan dengan menerapkan model pembelajaran Make a Match, yang memberikan hasil cukup baik yaitu siswa terlihat lebih aktif dari pada pembelajaran pada pra-siklus namun hasil belajar siswa yang belum mencapai Kriteria Ketuntasan Minimal yang ditetapkan sekolah. Pada siklus II, proses pembelajaran juga dilaksanakan dengan model pembelajaran Make a Match. Hasil observasi menunjukkan hasil yang sangat baik dan sudah melampaui pencapaian yang ditetapkan yaitu hasil belajar tinggi. 
Penelitian hasil belajar peserta didik pada penelitian ini memiliki kelebihan dibandingkan dengan penelitian-penelitian sebelumnya. Keunggulan penelitian ini dibandingkan penelitian sebelumnya yaitu penelitian ini adalah mengukur hasil belajar IPA siswa pada pembelajaran tematik dengan menggunakan model pembelajaran Make a Match. Selain itu dalam penelitian ini bukan hanya aspek kognitif yang dapat terlihat meningkat akan tetapi aspek afektif dan psikomotorik ikut meningkat. Penggunaan model pembelajaran Make a Match juga dapat menjadikan peserta didik lebih aktif dalam mengikuti pembelajaran karena peserta didik bisa belajar sambil bermain karena berusaha mencari pasangan yang tepat dari pertanyaan dan jawaban yang diberikan oleh guru, sehingga pembelajaran tersebut akan menjadi lebih mengasyikan dan tidak membosankan dan dapat meningkatkan perhatian siswa terhadap materi yang akan diajarkan pada siswa kelas 4 SD Negeri Kutowinangun 04 Salatiga Tahun Pelajaran 2018/2019.

\section{SIMPULAN}

Berdasarkan pada hasil penelitian tindakan kelas yang telah dilaksanakan dan pengujian hipotesis maka dapat disimpulkan bahwa Penerapan model pembelajaran Make a Match untuk meningkatkan hasil belajar IPA pada pesertadidik kelas IV SD Negeri Kutowinangun 04 Salatiga dilakukan dengan langkah- langkah sebagai berikut (1) guru menyiapkan beberapa kartu yang berisi beberapa konsep/ topik yang cocok untuk sesi review (satu sisi kartu berupa kartu soal dan sisi sebaliknya berupa kartu jawaban). (2) setiap peserta didik mendapat satu kartu (3) peserta didik mencari pasangan kartu (4) peserta didik yang dapat mencocokan kartunya sebelum batas waktu diberi poin. (5) setelah satu babak kartu dikocok lagi agar tiap peserta didik mendapat kartu yang berbeda dari sebelumnya, demikian seterusnya. (6) membuat kesimpulan. Selanjutnya, model pembelajaran make a match dapat meningkatkan hasil belajar IPA kelas IV di SD Negeri Kutowinangun 04 Salatiga. Hasil belajar IPA yang meningkat dapat dibuktikan dengan persentase ketuntasan hasil belajar peserta didik pada kondisi awal yaitu $14 \%$ meningkat menjadi $57 \%$ pada siklus I atau meningkat sebanyak $43 \%$. Persentase ketuntasan pada siklus II yaitu 93\% yang artinya mengalami peningkatan dari siklus I sebanyak 36\%.

\section{DAFTAR PUSTAKA}

Ariyanto, M. (2016). Peningkatan Hasil Belajar IPA Materi Kenampakan Rupa Bumi Menggunakan Model Scramble. Jurnal Profesi Pendidikan Dasar. Vol. 3 (2): 134-140.

Artawa, dkk. (2013). Pengaruh Model Pembelajaran Kooperatif Tipe Make A-Match Terhadap Prestasi Belajar Matematika Siswa Kelas V SD Di Gugus 1 Kecamatan Selat. Jurnal Mimbar PGSD Universitas Pendidikan Ganesha. Vol. 1 (1)

Iskandar. (2012). Penelitian Tindakan Kelas. Jakarta: GP Press Group.

Rusman. (2012). Model- Model Pembelajaran. Jakarta: PT Rajagrafindo Persada 
Sakarebau, E. S. (2017). Peningkatan Motivasi Belajar Siswa Dengan Menggunakan Model Kooperatif Tipe Make A Match Kelas IV SD. Jurnal Pendidikan Guru Sekolah Dasar. Vol 5: 389-397

Samino dan Marsudi, S. (2015). Layanan Bimbingan Belajar. Solo: Fairuz Media

Slameto. (2003). Belajar dan Faktor-faktor yang Mempengaruhinya. Jakarta: Rineka Cipta.

Sudjana, N. (2008). Penilaian Hasil Proses Belajar Mengajar. Bandung: Remaja Rosdakarya

Sugiyanto. (2010). Model-model Pembelajaran Inovatif. Surakarta: Yuma Pustaka

Trianto. (2011). Mendesain Model Pembelajaran Inovatif-Progressif. Jakarta: Kencana.

Yenti, dkk. (2016). Pengaruh Model Kooperatif Tipe Make A Match Terhadap Hasil Belajar Siswa Pada Materi Virus SMA. Jurnal Pendidikan Dan Pembelajaran Universitas Tanjungpura. Vol. 5 (9)

Wiguna, A., Sumantri, dan Raga. (2014). Pengaruh Model Pembelajaran Cooperative Tipe Make A-Match Terhadap Hasil Belajar Matematika Siswa Kelas IV Di Gugus III Kecamatan Rendang. Jurnal Mimbar PGSD Universitas Pendidikan Ganesha. Vol. 2 (1) 